\title{
Music reviews
}

\section{David J. Burn}

\section{The Pötzlinger project}

Der Mensuralcodex St. Emmeram. Faksimile der Handschrift Clm 14274 der Bayerischen Staatsbibliothek

München, commentary by Ian Rumbold with Peter

Wright, 2 vols. (Wiesbaden: Reichert, 2006), €258

Hermann Pötzlinger was unknown to musicologists before a pair of pioneering articles by Ian Rumbold and Dagmar Braunschweig-Pauli, both published in 1982, independently identified him as the owner and main copyist of the so-called 'St Emmeram Codex' (Munich, Bayerische Staatsbibliothek, Clm 14274). The codex, a substantial manuscript of almost 160 folios, is one of the most important surviving witnesses to polyphony in German-speaking lands in the second quarter of the 15th century. It was first brought to widespread attention by Karl Dèzes in 1927-8, yet its frequent dismissal since that time as peripheral meant that it escaped detailed study. Rumbold and Braunschweig-Pauli's identification of its owner/compiler sparked a revival of interest that led both Rumbold and Braunschweig-Pauli themselves, and others such as Reinhard Strohm, Bernhold Schmid, Tom Ward and Lorenz Welker to address many of the basic unanswered questions concerning the

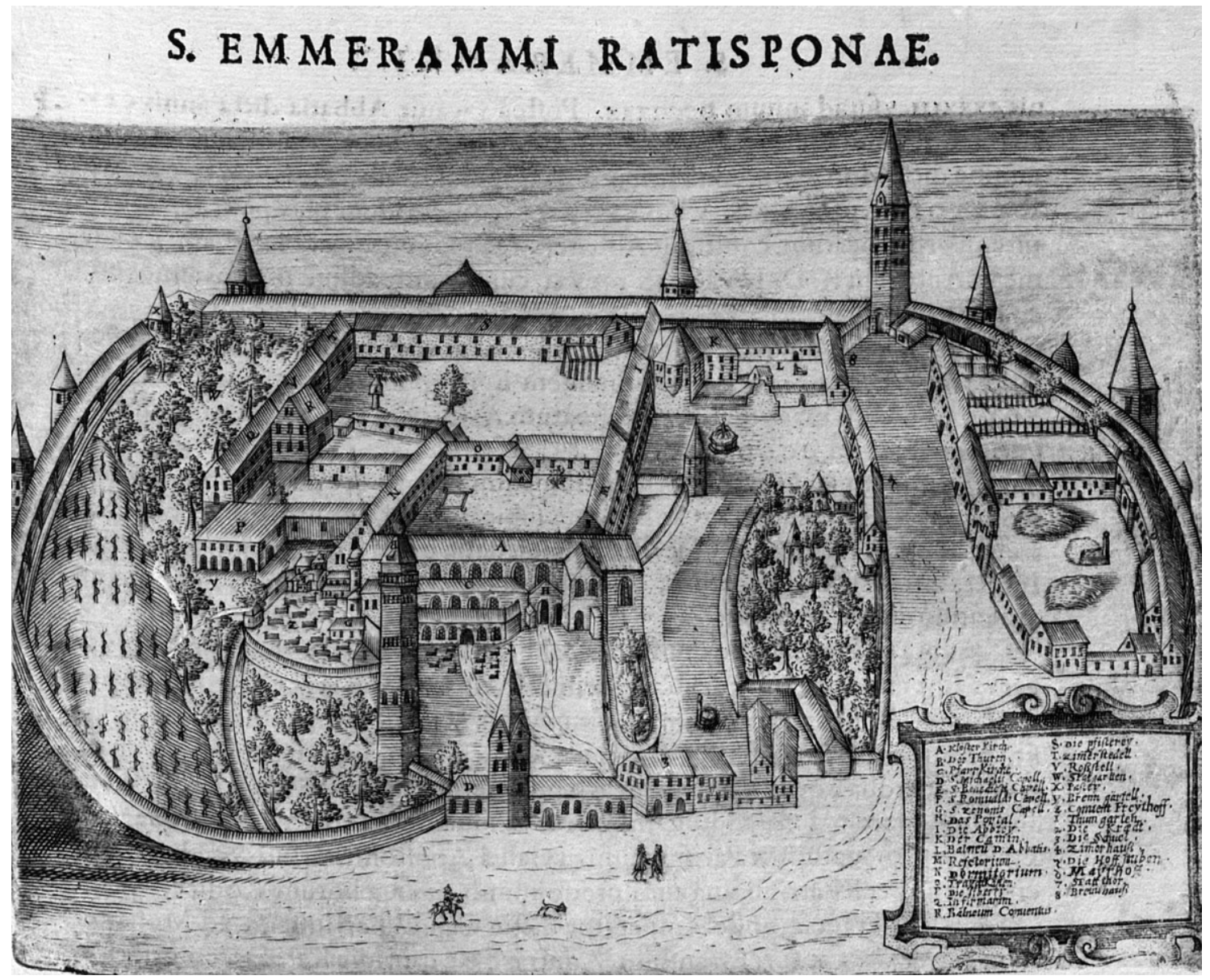

Plan of the monastery of St Emmeram (Carl Stengel, Monasteriologia, 2 vols. (Augsburg, 1619-38), i, [17] (Munich, Bayerische Staatsbibliothek) (with permission) 


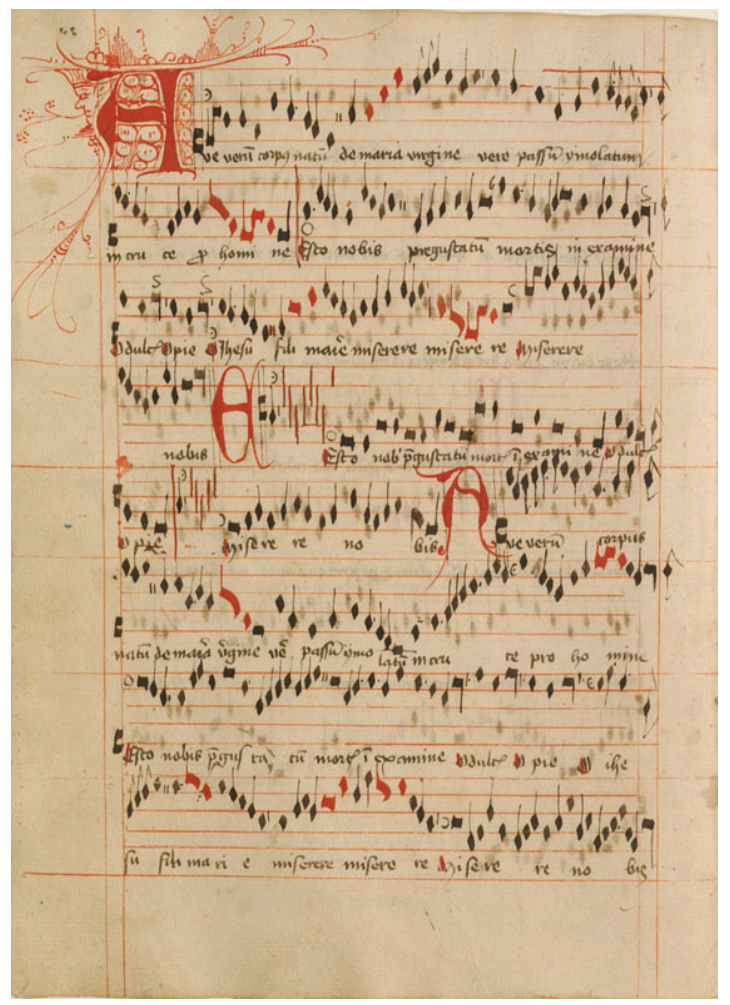

Munich, Bayerische Staatsbibliothek, Clm 14274, fol. $29 v$ (with permission)

source's history, function, compilation, repertory and significance. The publication of the codex in facsimile marks a first culmination-point in drawing this work together. Two further instalments are eagerly awaited: a monograph, jointly authored by Rumbold and Peter Wright, resulting from a major project on the codex carried out at the University of Nottingham between 2004 and 2007 with funding from the Arts and Humanities Research Council; and a critical edition, by Bernhold Schmid and Tom Ward.

The 150-page commentary volume, in English and German, provides a state-of-the-art guide to the source. The bulk of it presents the first fruits of Rumbold and Wright's collaborative research. Every anticipated aspect is touched upon, with physical makeup, scribes and compilation receiving particularly thorough treatment. A brief introduction by Martin Staehelin succinctly highlights the most important aspects of the codex's significance, and an extensive bibliography is provided.

Understanding the codex begins with the biography of its owner. Though Pötzlinger was evidently well trained in music, it was never his profession, so far as is known. He first appears in the matriculation register of the Univer- sity of Vienna in 1436. After graduating in 1439, he is documented as a priest in the diocese of Bamberg in the same year. By 1448 he was teaching at the monastery school of St Emmeram in Regensburg. Notwithstanding a few sojourns elsewhere, he maintained connections to that institution for the rest of his life. The monastery granted him a house in which to retire, and he was buried there on his death in 1469. In return, he bequeathed 110 books to the monastery library. Along with the rest of the St Emmeram collection, they were transferred in 1811 to what would become the Bayerische Staatsbibliothek and still survive there more or less in their entirety. The clever detective-work behind attaching the codex to the Pötzlinger bequest hinged on scribal concordances with books known to be his, as well as shared watermarks and binding strips. The latter, detached from the codex in 1966, are reproduced in colour in Rumbold and Wright's commentary, reassembled into the pages they once formed, along with appropriate comparative material.

It was due to the codex's inclusion among the St Emmeram collection that it gained the name by which it is still known. Yet Rumbold and Wright's research on its dating suggests that its compilation may have taken place before Pötzlinger's arrival in Regensburg. Comparison of the 12 papertypes in the codex with standard watermark catalogues and, more decisively, with other Pötzlinger manuscripts in which the same paper-types sometimes appear with a date, places its copying largely between 1439 and 1444. The authors admit that their results are provisional, but future work seems most likely to nuance, rather than radically alter, their picture. Images of all the codex's watermarks are given, though their reproduction is the single sub-optimal aspect of the documentation, due to technological limitations plainly acknowledged by the authors. From meticulous analysis of everything down to the tiniest prick-marks, the authors propose a compilation in at least three stages.

It is unfortunate that the years during which Pötzlinger was compiling his codex fall within a biographical lacuna. An answer to the question of his whereabouts in these years is among the more pressing of the yet unresolved issues surrounding the source. Wherever he was, he does not appear to have had any particularly privileged musical access. The contents of his manuscript are thus a telling witness to the music that was then available to anyone within his milieu with an interest in acquiring it. Rumbold and Wright provide an excellent general overview of the repertory and a comprehensive new inventory, pending in-depth consideration of individual pieces in the monograph and edition. The 255 codex-items (including eight duplicates) are a bewilderingly varied collection of works 
from all over Europe from the late 14th century onwards. More than half are unica. The codex has no systematic overall organization, but small repertory-groups occur, such as works by a particular composer (e.g. nos.244-6, by Johannes Roullet, for whom the codex is the single most important source), works in a particular genre (e.g. nos.133-8, all introits) or works with the same function (e.g. nos.42-3, both for St Martin). Around 80 per cent of the pieces are sacred, with individual movements for the Proper and Ordinary of the Mass the most numerous. Works in fauxbourdon are unusually prominent, for unclear reasons (personal preference or ease of performance?). The remaining secular repertory, mostly French song, invariably appears either without text or as Latin contrafacta. Staehelin accounts for the phenomenon as simple linguistic incomprehension, but similar textual omission in the handful of German songs and the occasional double-texting of Latin works suggests that there may have been deeper reasons at work.

Just under half the pieces can be attributed. Dufay clearly heads the list with 39 works, including several unica. Concordances for works of his known from other sources do more than just provide extra readings. In the case of Supremum est mortalibus, the alteration of the closing words to honour Beatrix of Munich and her husband Pfalzgraf Johann of Neumarkt offers fascinating insights simultaneously into the work's reception and the transmission-paths by which Pötzlinger acquired his repertory. An influx of English music, by Dunstaple and Power among others, in the later layers of the codex reflects larger contemporary trends. It is not the international repertory, however, but the local, that makes the codex uniquely valuable and distinctive. Among this group, the occasional composer-name, such as Hermann Edlerawer, cantor at Vienna's St Stephen's Cathedral at the time Pötzlinger was compiling his manuscript, gives a tantalizing snapshot into Pötzlinger's personal circle. More than 100 works, however, are both anonymous and unknown outside the codex. New insights into this easily sidelined repertory will be among the most interesting avenues for future research. Perhaps Pötzlinger himself not only copied, but also composed, some of the pieces.

The facsimile itself is superb. The source is presented at its original size, and runs complete from inside front-cover to inside back-cover in full colour apart from four now-lost pages that had to be recovered from microfilm. The high resolution renders even the subtlest details visible. The astronomical price-tag that such quality usually implies was offset by a generous subsidy from the Oberfrankenstiftung.
In a foreword to the commentary volume, the Director General of the Bayerische Staatsbibliothek, Dr Rolf Griebel, explicitly states that the facsimile aims to stimulate not only further scholarly investigation of the codex, but also performance of the music. Many of the pieces can be sung direct from the source without difficulty. Some, however, pose challenges, including unorthodox or distinctively Central European notational practices, unusual clef-usage, parts written an octave lower than they are intended to sound, unsignalled application of a parallel voice in fauxbourdon, and corrupt readings, particularly in the (fortunately brief) work of the second of the codex's main scribes, whose habit was to write note-heads first, then only later, and not always accurately, add the stems.

Rumbold and Wright have already taken a vital first step in bringing the codex's music to life by collaborating with the Munich-based vocal ensemble Stimmwerck in the production of a splendid recording, The St Emmeram Codex (Aeolus AE 10023, rec.2007, 74'). This contains 21 pieces, interspersed with seven intabulations from the Buxheim Organ Book of pieces that also appear in the codex. The charms of works such as the delightful Levat autentica, perhaps by Rudolf Volkhardt von Häringen, or Petrus Wilhelmi de Grudencz's rollicking Presulem euphebeatum, with its bilingual goose-themed doubleentendres, may be missed by visual assessment alone, but speak immediately to the ear. The disc is an inspiration to discover what other treats the codex has in store.

In Rumbold's liner-notes, nuggets of information absent from the facsimile offer teasers for the forthcoming monograph: among others, that Pötzlinger most likely remained in Vienna in the crucial years between 1439 and 1448; that Dufay's Supremum est mortalibus with its altered text may have been performed in Regensburg or at the Council of Basel following a major victory over the Hussites in 1433; and that Wolfgang Chranekker, organist of the church of St Wolfgang on the Abersee, helped in the codex's compilation. Along with its companion-studies, the facsimile will undoubtedly make the St Emmeram codex less easy to overlook than it has been in the past. Thanks to all involved, it is on its way to becoming a central European source in every sense.

The new study of the St Emmeram Codex by Ian Rumbold and Peter Wright entitled Herman Pötzlinger's music book. The St Emmeram Codex and its contents will shortly be published in the Boydell Press's Studies in Medieval and Renaissance Music series.

doi:10.1093/em/cap011 